\title{
Holocene tree immigration and the chironomid fauna of a small Swiss subalpine lake (Hinterburgsee, $1515 \mathrm{~m}$ asl)
}

\author{
Oliver Heiri ${ }^{\mathrm{a}, *}$, Lucia Wick ${ }^{\mathrm{b}}$, Jacqueline F.N. van Leeuwen ${ }^{\mathrm{b}}$, \\ Willem O. van der Knaap ${ }^{\mathrm{b}}$, André F. Lotter ${ }^{\mathrm{a}}$ \\ a Botanical Palaeoecologicy, Laboratory of Palaeobotany en Palynology, Universiteit Utrecht, Budapestlaan 4, \\ 3584 CD Utrecht, Netherlands \\ b Institute of Plant Sciences, University of Bern, Altenbergrain 21, CH-3013 Bern, Switzerland
}

Received 26 July 2001; received in revised form 25 June 2002; accepted 15 October 2002

\begin{abstract}
Early Holocene reforestation by stone pine (Pinus cembra) and tree birch (Betula pubescens) took place ca. 500 years after the end of the Younger Dryas at Hinterburgsee, a small subalpine lake in the northern Swiss Alps. During the next ca. 3000 years the local vegetation consisted of open woodlands with many pioneer dwarf shrubs and herbs. The expansion of silver fir (Abies alba) at ca. 7400 calibrated radiocarbon years before present (cal. BP) and Norway spruce (Picea abies) at ca. 6000 cal. BP in Hinterburgsee's catchment led to a closing of the local forests with a successive decrease in erosion and a distinct change in Hinterburgsee's sediment composition. First signs of probably human-induced openings of the catchment forest are apparent at ca. $2500 \mathrm{cal}$. BP, but it is not until the past ca. 800 years that pollen analysis suggests strong local and regional anthropogenic activity. The strongest and most abrupt changes in the Holocene development of Hinterburgsee's chironomid fauna took place at ca. $11500 \mathrm{cal}$. BP and at ca. $10000 \mathrm{cal}$. BP, when parts of the alpine taxa that were dominant during the Younger Dryas disappeared from the lake. The first change is most likely related to the increasing temperatures after the end of the Younger Dryas, the second possibly to decreasing lake depth and increasing summer insolation in the early Holocene that may have led to warmer bottom water temperatures in the lake. No clear relationship between the changes in catchment vegetation and the development of the chironomid fauna was found. Possibly the increase in sediment organic matter associated with the denser catchment forests was responsible for a succession in the chironomid stratigraphy between 7000 and $4500 \mathrm{cal}$. BP. However, due to the high sedimentation rates in Hinterburgsee this trend could also be a consequence of, or be promoted by, the sediment infilling of the lake basin. This conjecture is supported by the increasing importance of Tanytarsus lugens-type, a chironomid taxon dominant in the extant chironomid assemblages of shallow mountain lakes in Switzerland. The only shift in the chironomid fauna that clearly parallels a change in catchment vegetation is found during the past ca. 800 years. We discuss possible reasons for the comparatively weak influence of catchment vegetation on the chironomid fauna of Hinterburgsee and the implications of our results for multi-proxy studies on past climate involving both palaeobotanical and chironomid-based reconstructions.
\end{abstract}

(C) 2002 Elsevier Science B.V. All rights reserved.

Keywords: palaeolimnology; Holocene; subalpine lake; chironomids; vegetation history; catchment-lake interactions

* Corresponding author. E-mail address: o.heiri@bio.uu.nl (O. Heiri).

0031-0182/02/\$ - see front matter (C) 2002 Elsevier Science B.V. All rights reserved.

PII: S $0031-0182(02) 00592-8$ 


\section{Introduction}

The Holocene period is receiving increasing attention by palaeoecologists and palaeolimnologists because human-induced changes on terrestrial and limnic ecosystems can only be assessed in relation to the natural, millennium-scale dynamics of these systems before the onset of anthropogenic influence (e.g. Anderson and Battarbee, 1994; Itkonen et al., 1999; Lotter, 2001). Furthermore, Holocene palaeoclimate reconstructions are necessary in order to examine the natural climate variability, the relationship of climate to possible forcing mechanisms and to understand the significance and causes of the global warming trend during the past century (Bradley, 2000).

Small mountain lakes in the Alpine region provide an interesting setting for studies of past vegetation, limnology, and climate. The steep catchment topography often leads to high allochthonous sediment input and therefore to high sedimentation rates. Thus, the sediments in these lakes provide high-resolution archives for palaeoecological and palaeoclimatological studies. If the lakes are situated in the lower alpine or subalpine vegetation zone, palaeobotanical studies can provide insights to changes in past timberline elevation. As temperature is one of the factors limiting tree growth at alpine timberlines (Tranquillini, 1979), the reconstruction of former treeline altitude offers information on past climate (e.g. Burga, 1993; Wick and Tinner, 1997). Major tree immigration paths into the Alpine region can be inferred, providing information of interest to biogeography and plant ecology. Furthermore, subfossil assemblages of aquatic organisms can be studied in the same sediment as the palaeobotanical proxies. A survey of the remains of diatoms, chrysophyte cysts, cladocera and chironomids in the surface sediments of small Swiss lakes suggests that in the Alps subfossil assemblages in lakes just below the present-day timberline are exceptionally sensitive to temperature changes (Lotter et al., 1997a). The distribution of some of these, e.g. the remains of chironomid larvae (Insecta: Diptera: Chironomidae), is strongly related to summer temperature (Walker et al., 1991b; Lotter et al., 1997a; Olander et al.,
1999) and they can thus be used to model quantitatively past air or water temperatures (e.g. Walker et al., 1991a; Levesque et al., 1993). Therefore, besides providing background information on the long-term development of lake ecosystems, Holocene chironomid stratigraphies can provide an additional estimate of past climate change. Finally, instrumental records indicate that changes in climate in the Alps may be more distinct at high elevations than in the lowlands (Beniston et al., 1997). Thus, palaeoclimatological studies in alpine and subalpine lakes may pick up temperature signals that are too weak to affect terrestrial or aquatic ecosystems at lower altitudes.

A number of multi-proxy studies with a focus on reconstructing past climate have recently been implemented in the Alpine region (e.g. Ammann, 2000; Lotter et al., 2000; Lotter and Birks, accepted). They combine information on former terrestrial vegetation and aquatic lake biota to produce more reliable environmental reconstructions than would be possible in single-proxy studies. Sensu stricto quantitative organism-based inference models assume that environmental variables other than the parameter of interest have a negligible influence on fossil assemblages during the period of reconstruction (Birks, 1995). However, in polar regions there is a distinct change in lake water chemistry across the tundra-boreal forest ecotone (e.g. Anderson, 2000; Smol and Cumming, 2000). In addition, palaeolimnological evidence suggests that in more temperate regions the immigration of new tree species into a lake's catchment can significantly affect lake water chemistry and thereby phytoplankton assemblages (e.g. Korsman et al., 1994). For chironomids a change of assemblage composition with the arctic treeline has been reported (Walker and MacDonald, 1995; Porinchu and Cwynar, 2000). In the Alps, limnological changes associated with the treeline ecotone seem to be less pronounced (Lotter et al., 1997a, 1998; Müller et al., 1998). Nevertheless, when reconstructing past temperatures using quantitative inference models based on chironomids, changes in the catchment vegetation may possibly be responsible for shifts in the chironomid assemblages. There exists, therefore, the danger of cir- 
cular argumentation when using palaeobotanical data to support quantitative chironomid-based temperature reconstructions from the same sediment or vice versa. This is particularly a problem for the Holocene, as anticipated temperature changes are small and local artefacts may be more difficult to separate from the climate signal than during periods with more pronounced climate changes.

Here we present the results of a multi-proxy Holocene study of Hinterburgsee, a small lake in the subalpine zone of the Swiss Alps. Pollen and plant macrofossil analysis is used to describe the vegetation history in Hinterburgsee's catchment. Furthermore, a chironomid stratigraphy from Hinterburgsee is presented and major trends in the long-term development in the chironomid assemblages are discussed. Finally, as the lake's catchment has experienced distinct shifts in vegetation, the vegetation history is compared to changes in the chironomid fauna to assess if catchment vegetation development is a major factor affecting the chironomid assemblages.

\section{Study site}

Hinterburgsee is a small mountain lake situated at $1515 \mathrm{~m}$ asl on calcareous bedrock in the northern Swiss Alps $\left(8^{\circ} 4^{\prime} 03^{\prime \prime} \mathrm{E}, 46^{\circ} 43^{\prime} 06^{\prime \prime} \mathrm{N}\right)$. It is located above the southern shore of Lake Brienz, ca. $16 \mathrm{~km}$ east of Interlaken and $4.5 \mathrm{~km}$ south to southeast of Brienz (Fig. 1A). Parts of the catchment above the southern lake shore consist of a precipice, whereas the remaining slopes show a more gentle incline. Hinterburgsee has one major tributary on the western shore that is active mainly during spring. The lake is drained by a sinkhole on the northern shore (Fig. 1B). Due to the lake's constant water level and outflow it is assumed that part of the water inflow takes place subterraneously (Guthruf et al., 1999). The lake has a major basin with a maximum depth of $11.1 \mathrm{~m}$ and a minor basin in the eastern part (Fig. 1B). The surrounding vegetation consists mainly of Norway spruce (Picea abies) and, especially on the steep southern slopes, of green alder (Alnus viridis). Bare rock in the form of cliffs on the southern precipice and as boulders and blocks on the other slopes makes up ca. $15 \%$ of the total catchment. Several meadows and parts of the open woodlands are used for summer pasturing (Spengler, 1973). Lake water chemistry measurements indicate meso- to eutrophic conditions in the lake today with $33 \mu \mathrm{g}$ total phosphorus $1^{-1}$ and $1.16 \mathrm{mg}$ total nitrogen $1^{-1}$ (averaged over the whole water column). Hinterburgsee generally freezes from mid-October to mid-November and thaws around mid-May (Spengler, 1973).

\section{Methods}

In August 1997, two parallel cores were taken in the deepest part of the lake (Fig. 1B) using a modified 8-cm-diameter Livingstone piston corer (Merkt and Streif, 1970; Lotter et al., 1997b). The two cores were taken within a horizontal distance of $1 \mathrm{~m}$ and with a vertical offset of $50 \mathrm{~cm}$ (henceforth referred to as core A and core B). A gravity corer (Renberg, 1991) was used to sample the topmost $60 \mathrm{~cm}$ of water-saturated sediment. The core segments of $1 \mathrm{~m}$ length were extruded from the stainless steel tubes on site and transported to the laboratory, where they were lengthwise cut into halves using two copper sheets. The sheets were inserted into the sediment cores laterally and the two core halves separated, each with one copper sheet covering the freshly cut sediment. After the cores had been photographed, described lithologically and correlated, one half core of the sequence was contiguously sampled for different analyses, the other half stored as reference.

Loss-on-ignition (LOI) analyses were carried out on $1-\mathrm{cm}^{3}$ samples of sediment and in approximately $10-\mathrm{cm}$ intervals following the recommendations in Heiri et al. (2001) (i.e. $4 \mathrm{~h}$ of combustion at $550^{\circ} \mathrm{C}$ for the estimate of organic matter content and $2 \mathrm{~h}$ at $950^{\circ} \mathrm{C}$ for the estimate of carbonate content). For pollen analysis $1 \mathrm{~cm}^{3}$ of sediment was prepared using standard methods with $10 \% \mathrm{KOH}, 10 \% \mathrm{HCl}, 40 \%$ hydrofluoric acid (HF) and acetolysis (see Fægri and Iversen, 1989), mounted in glycerine and identified under a compound microscope at $1000 \times$ magnification (average count sum: 500 pollen grains per sam- 
A
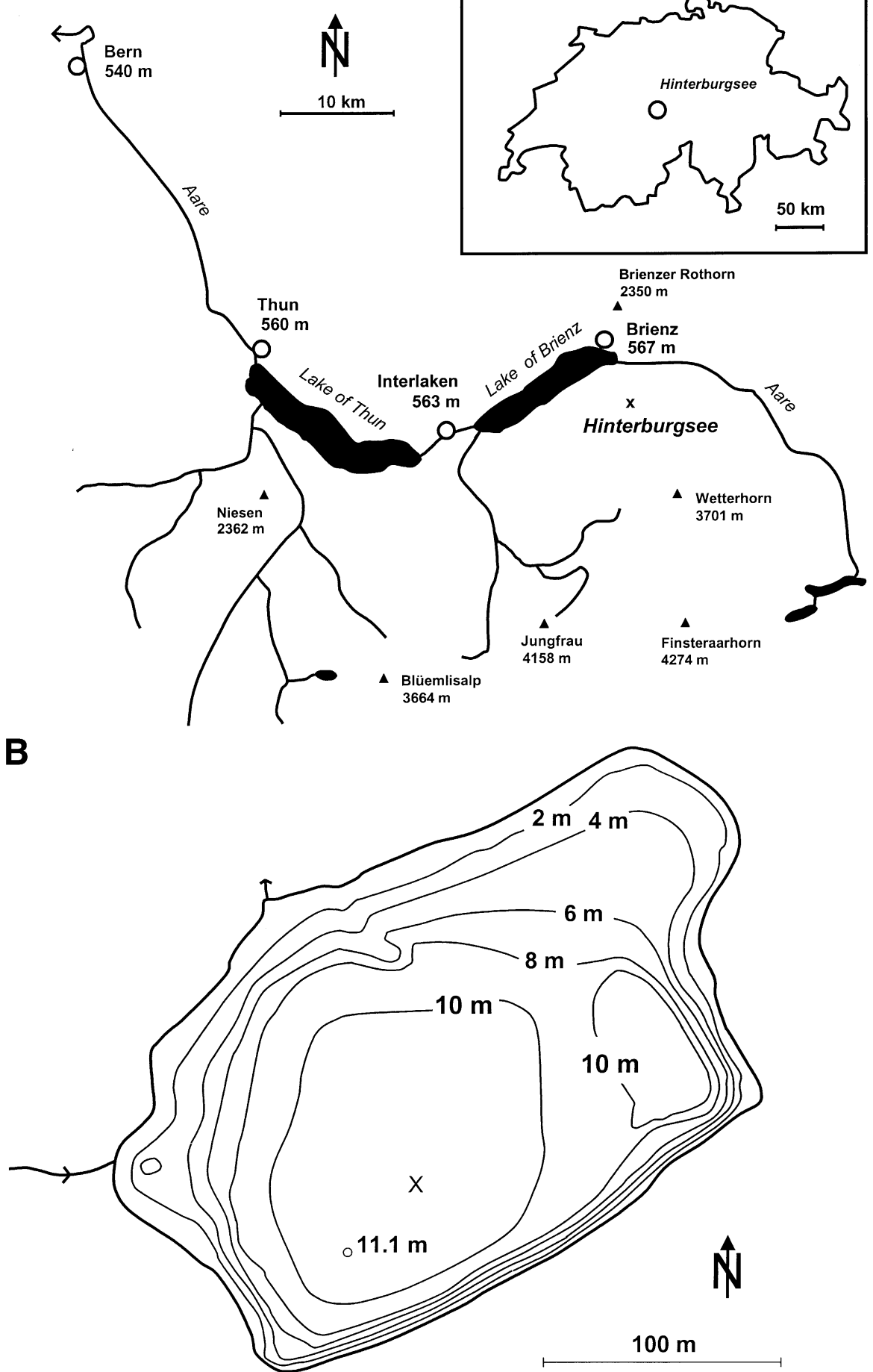

Fig. 1. (A) Location of Hinterburgsee in the Bernese Alps (detailed map) and within Switzerland (inset map). (B) Bathymetry of Hinterburgsee (following Spengler, 1973, changed). The open circle indicates the deepest part of the lake basin and the $\times$ the coring site. 
ple). Pollen percentages were calculated excluding aquatic plant pollen from the total pollen sum. For plant macrofossil and chironomid analysis, sediment slices of $2 \mathrm{~cm}$ thickness and ca. 30-40 $\mathrm{cm}^{3}$ volume were immersed in $5 \% \mathrm{KOH}$ for $2-3 \mathrm{~h}$ and subsequently sieved through a $200-\mu \mathrm{m}$ and a $100-\mu \mathrm{m}$ sieve. The $200-\mu \mathrm{m}$ fraction was examined for plant macrofossils and charcoal under a stereomicroscope and large terrestrial plant remains were set aside for radiocarbon dating. After joining the $200-\mu \mathrm{m}$ and $100-\mu \mathrm{m}$ fractions the residue was examined for subfossil chironomids. Due to the minerogenic nature of the sediment, chemical treatment of the residue with HF was necessary to eliminate the inorganic sediment components (see Walker and Mathewes, 1989). Head capsule concentrations were very variable and therefore a modified two-chamber subsampler (Meyer, 1990) was used to reduce the size of some samples before picking the chironomid remains at $35 \times$ magnification under a stereomicroscope. Chironomids were mounted in Euparal ${ }^{\circledR}$ mounting medium after dehydration and identified at $100 \times$ and $400 \times$ magnification with a compound microscope. Taxonomy mainly follows Hofmann (1971), Wiederholm (1983), Schmid (1993) and Rieradevall and Brooks (2001). The identification of Micropsectra spp., Micropsectra radialis-, Corynoneura scutellata- and Tanytarsus lugens-type is described in detail in Heiri (2001) and of Tanytarsus A, Cricotopus- and Orthocladius-type in Lotter et al. (1997a). Psectrocladius (s.str.) includes all Psectrocladius head capsules not of a Psectrocladius (Allopsectrocladius)- or Psectrocladius (Mesopsectrocladius)-type as described in Wiederholm (1983). Paratanytarsus spp. contain all Paratanytarsus except Paratanytarsus austriacus-type (i.e. all without the combination of a pigmented head capsule and three inner teeth on the mandible). Finally, Zavrelimyia A has dorsal head capsule pores that, instead of forming almost a right angle as described for Zavrelimyia punctatissima in Rieradevall and Brooks (2001), are arranged in a curved row, forming a broader angle (ca. $\left.120^{\circ}\right)$.

Besides larval head capsules, two types of respiratory organs (thoracic horns) of pupae of the genus Procladius were isolated from the sediment.
Procladius type 1 pupae feature an elongate thoracic horn with a length to width ratio of 3.7 to 4.1 $(n=5)$, with the widest part in the middle of the horn (e.g. as described for Procladius choreus or Procladius signatus in Langton, 1991). Procladius type 2 thoracic horns, on the other hand, were flattened as described for 'Procladius tatrensis' in Gowin and Zavrel (1944) with a length to width ratio of 2.0 to 2.3 .

Detrended correspondence analysis (DCA) was carried out using the program CANOCO version 4.0 (ter Braak and Smilauer, 1998) and using untransformed percentage data and downweighting of rare species. The partitioning of the stratigraphies into assemblage zones was accomplished by eye.

\section{Results}

\subsection{Lithology}

Sediment to $1280 \mathrm{~cm}$ below the sediment/water interface was obtained from both cores A and B. It was not possible to acquire deeper sediment from core A. Core B reached to a depth of 1575 $\mathrm{cm}$ below the sediment/water interface, where further penetration of the corer was impeded by a gravel layer of at least $24 \mathrm{~cm}$ thickness. The sediment cores were correlated using lithological features (turbidites, slumps and sand layers) to produce a continuous sediment sequence down to a depth of $1280 \mathrm{~cm}$ below the sediment/water interface. As the corresponding sequences of core A are not available for the lowermost sediments there are two hiatus of approximately $10 \mathrm{~cm}$ thickness between the last three core segments of core B (Fig. 2a).

A total of $30 \%$ of the Hinterburgsee deposits consist of turbidites, slumps or sand layers. As such sequences represent single, abrupt sedimentation events and tend to incorporate reworked organic material, they disturb the chronological order of the sediment and can seriously bias stratigraphic analyses of organic remains and age-depth relationships. Therefore, except where otherwise indicated all references to sediment depth henceforth refer to a corrected sediment 
a.)

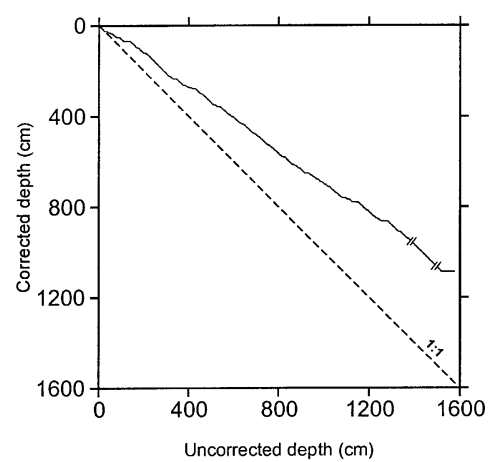

b.)

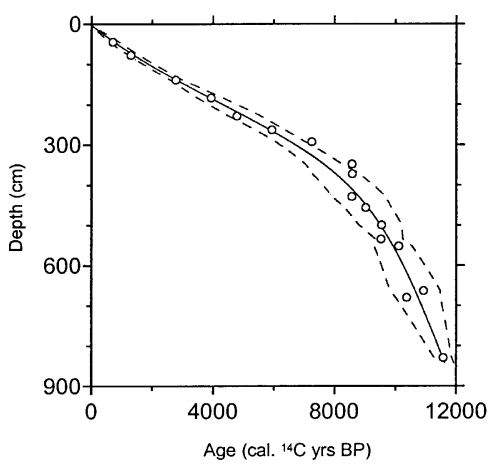

c.)
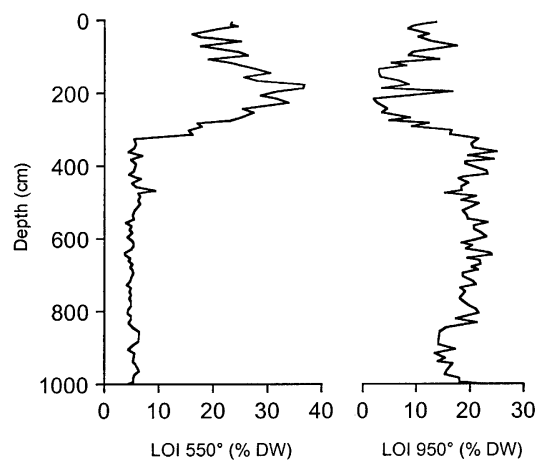

Fig. 2. (a) Relationship between corrected and uncorrected sediment depth in the Hinterburgsee core (solid line). The uncorrected depth is the core depth from the water/sediment interface, whereas for the corrected depth the turbidites and slumps were excluded. The interruptions in the curve indicate two hiatus of ca. $10 \mathrm{~cm}$ thickness. (b) Dating of the Hinterburgsee core: agedepth model (solid line) and 95\% confidence intervals (dotted lines). Circles indicate the calibrated dates used for the model (see Table 1). The sediment depth is plotted in corrected values (see text for details). (c) LOI as \% dry weight (DW) measured in the Hinterburgsee sediment. The sediment depth is plotted in corrected values (see text for details).

depth that excludes turbidites, slumps and sand layers (see Fig. 2a).

According to lithological characteristics, the sediment sequence can be roughly separated into two parts. Below ca. $310 \mathrm{~cm}$ sediment depth the deposits are highly minerogenic, with a low organic and high carbonate content (Fig. 2c). They consist of silty clays with intercalated sandy layers. The lacustrine sedimentation is interrupted by numerous slumps and turbidites ranging from a few millimetres up to $30 \mathrm{~cm}$ thickness. From a sediment depth of about $310 \mathrm{~cm}$ to the core top, the sediment consists of a calcareous fine-detritus gyttia (Fig. 2c). Again, the sediment features numerous turbidites and slumps in the same size range as in the lower part of the core. Furthermore, a number of thin $(<1 \mathrm{~cm})$ layers of woody debris and other coarse organic detritus were identified upon visual inspection.

\subsection{Chronology}

A total of 17 samples was AMS-radiocarbon dated, seven of which originate from slumps or turbidites (Table 1). The core top $(-47 \mathrm{cal}$. BP) and the Younger Dryas/Holocene boundary (10000 uncalibrated radiocarbon years BP, see results of pollen analysis for details) provided two further dates. One of the radiocarbon dates from a slump was excluded from the age-depth model as it was obviously too old compared to the other dates in the sequence (Ua-13,348; Table 1). The remaining 18 dates were converted to calibrated radiocarbon years before present using method $\mathrm{A}$ in the CALIB 4.1.2 program (Stuiver and Reimer, 1993). Age-depth modelling was accomplished using non-parametric weighted regression within the framework of generalised additive models (see Lotter and Birks, accepted, for details on the method). Both the core top and the Younger Dryas/Holocene boundary were forced by giving these dates significantly more weight than the radiocarbon dates. The simplest, parsimonious age-depth model was based on a variance function proportional to the mean and a four degrees of freedom equivalent smoothing parameter. For the final age-depth model, ages were estimated by interpolation for every centimetre and the 95\% confidence interval calculated for each depth (Fig. 2b). Henceforth, all references to ages are given in these estimated calibrated radiocarbon ages (abbreviated as cal. BP). As the oldest date in the Hinterburgsee core is at ca. 11500 cal. BP, the older sediment remains undated. For graphical representation a constant sedimentation rate of $5.3 \mathrm{yr} \mathrm{cm}^{-1}$ is assumed for Late Glacial sediments (i.e. the same sedimentation rate as calculated for the oldest Holocene sediments). 
Table 1

Dates used for the Hinterburgsee age-depth model

\begin{tabular}{lccrll}
\hline Sample/laboratory No. & $\begin{array}{l}\text { Depth } \\
(\mathrm{cm})\end{array}$ & $\begin{array}{l}\text { Uncal. } \\
{ }^{14} \text { C years BP }\end{array}$ & $\begin{array}{l}\text { S.D. } \\
\text { Cal. }\end{array}$ & Remarks \\
\hline Core top & 0 & -47 & - & -47 & Sediment/water interface \\
Ua-14,630 & 45 & 805 & \pm 60 & 701 & - \\
Ua-14,631 & 78 & 1425 & \pm 60 & 1306 & Possibly slump \\
Ua-14,632 & 138 & 2665 & \pm 65 & 2760 & - \\
Ua-13,347 & 183 & 3625 & \pm 65 & 3919 & - \\
Ua-13,642 & 226 & 4215 & \pm 95 & 4767 & - \\
Ua-14,633 & 262 & 5145 & \pm 80 & 5912 & Slump \\
Ua-13,348 & 277 & 8000 & \pm 90 & 8874 & Slump, excluded from age-depth model \\
Ua-14,634 & 290 & 6375 & \pm 95 & 7235 & Detritus \\
Ua-14,635 & 347 & 7835 & \pm 90 & 8555 & Turbidite \\
Ua-14,636 & 371 & 7880 & \pm 80 & 8578 & - \\
Ua-13,643 & 427 & 8105 & \pm 85 & 8988 & Slump \\
Ua-14,637 & 454 & 8660 & \pm 110 & 9538 & - \\
Ua-13,644 & 898 & 9560 & \pm 85 & 9492 & Turbidite \\
Ua-14,638 & 534 & 9635 & \pm 95 & 10892 & Wood layer/detritus \\
Ua-13,349 & 552 & 9370 & \pm 115 & 10359 & Turbidite \\
Ua-13,350 & 664 & 10000 & - & 11550 & Pollen-inferred age \\
Ua-13,645 & 678 & & &
\end{tabular}

All depth values are in the corrected depth scale (see text for details).

\subsection{Pollen}

The deepest pollen samples retrieved from Hinterburgsee show a flora typical of Swiss Late Glacial sediments, with a high percentage of Pinus (subgenus Pinus), Betula, Gramineae, and Artemisia pollen (pollen assemblage zone (PAZ)-1; Fig. $3)$. The dominance of Pinus pollen and high Artemisia percentages indicate that the whole Late Glacial sediment sequence (before 11500 cal. BP) originates from the Younger Dryas biozone (Wegmüller and Lotter, 1990; Wick, 2000). The decline in Gramineae and Artemisia pollen and the increase in Pinus cembra mark the Late Glacial/Holocene boundary (e.g. Wick and Tinner, 1997; Wick, 2000). The Holocene palynostratigraphy is dominated by the typical sequence of tree immigrations known from other Holocene sediment sequences from the Swiss Plateau and the Northern Swiss Alps (e.g. Ammann et al., 1996; van der Knaap and Ammann, 1997). During PAZ-2, Pinus cembra is joined by Corylus avellana, Ulmus, Tilia, Quercus and Alnus glutinosa- type. At the end of PAZ-3 (ca. 7500 cal. BP), Abies percentages increase, later followed by $\mathrm{Pi}$ cea, Fagus and Alnus viridis during PAZ-4 and 5. The younger sediments of Hinterburgsee indicate increasing human activity near the lake. Plantago lanceolata-type appears at ca. $4000 \mathrm{cal}$. BP, later followed by a gradual increase of Gramineae and successive increases of other grazing and culture indicators such as Rumex acetosa-type, Rumex alpinus, Plantago alpina-type and Urtica. These pollen types are commonly associated with pasturing and feature the highest percentages in PAZ-6 (i.e. in the last ca. 800 years). Furthermore, the Hinterburgsee stratigraphy shows relatively high values of pollen and spores from plants indicating open woodlands or soil instability (e.g. Monolete fern spores, Dryopteris filix-mas-type, Pteridium aquilinum, Athyrium filix-femina, Selaginella selaginoides).

\subsection{Plant macrofossils}

The Late Glacial and earliest Holocene sedi- 


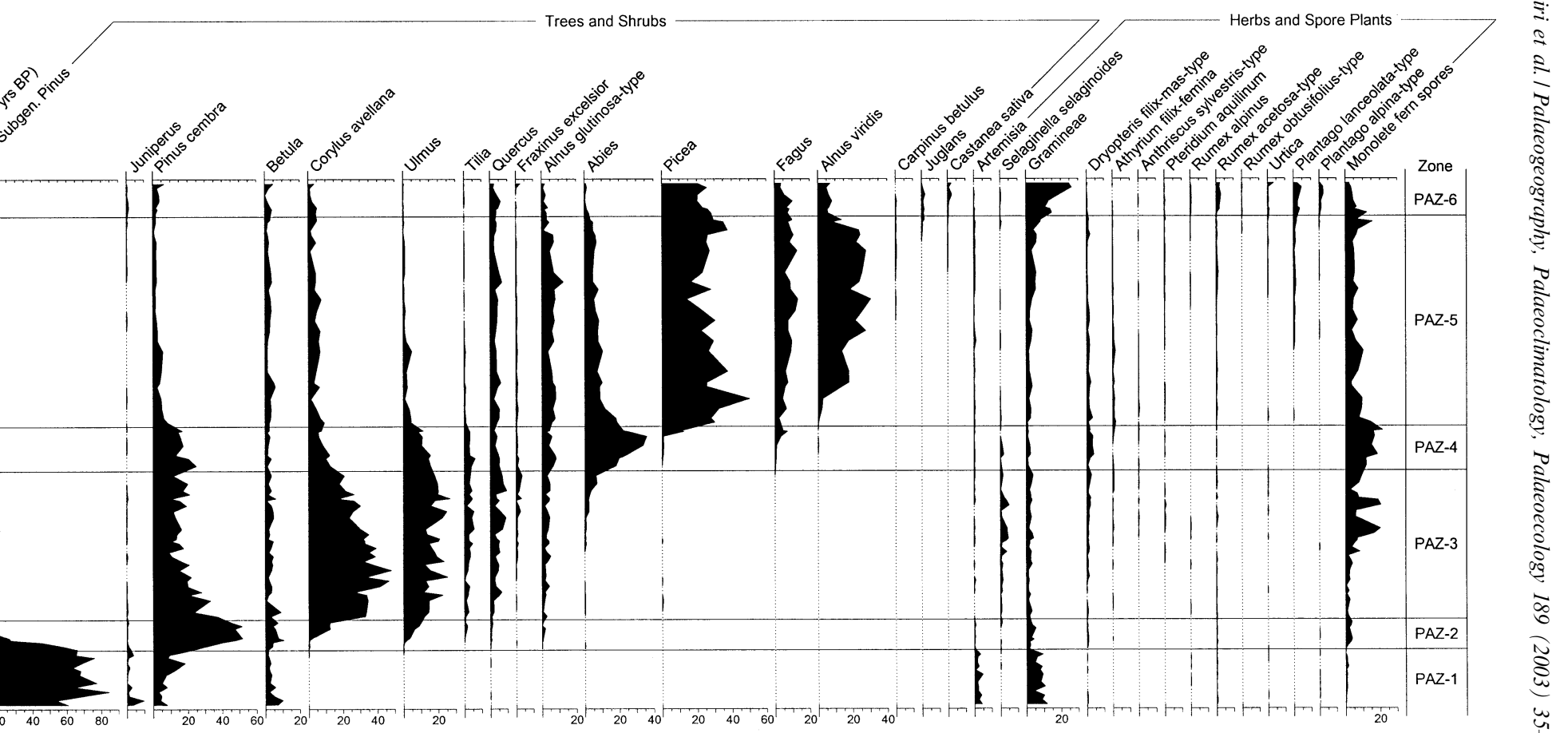

Fig. 3. Pollen stratigraphy of Hinterburgsee (values in percentages of total terrestrial pollen). Only selected pollen types are shown. 


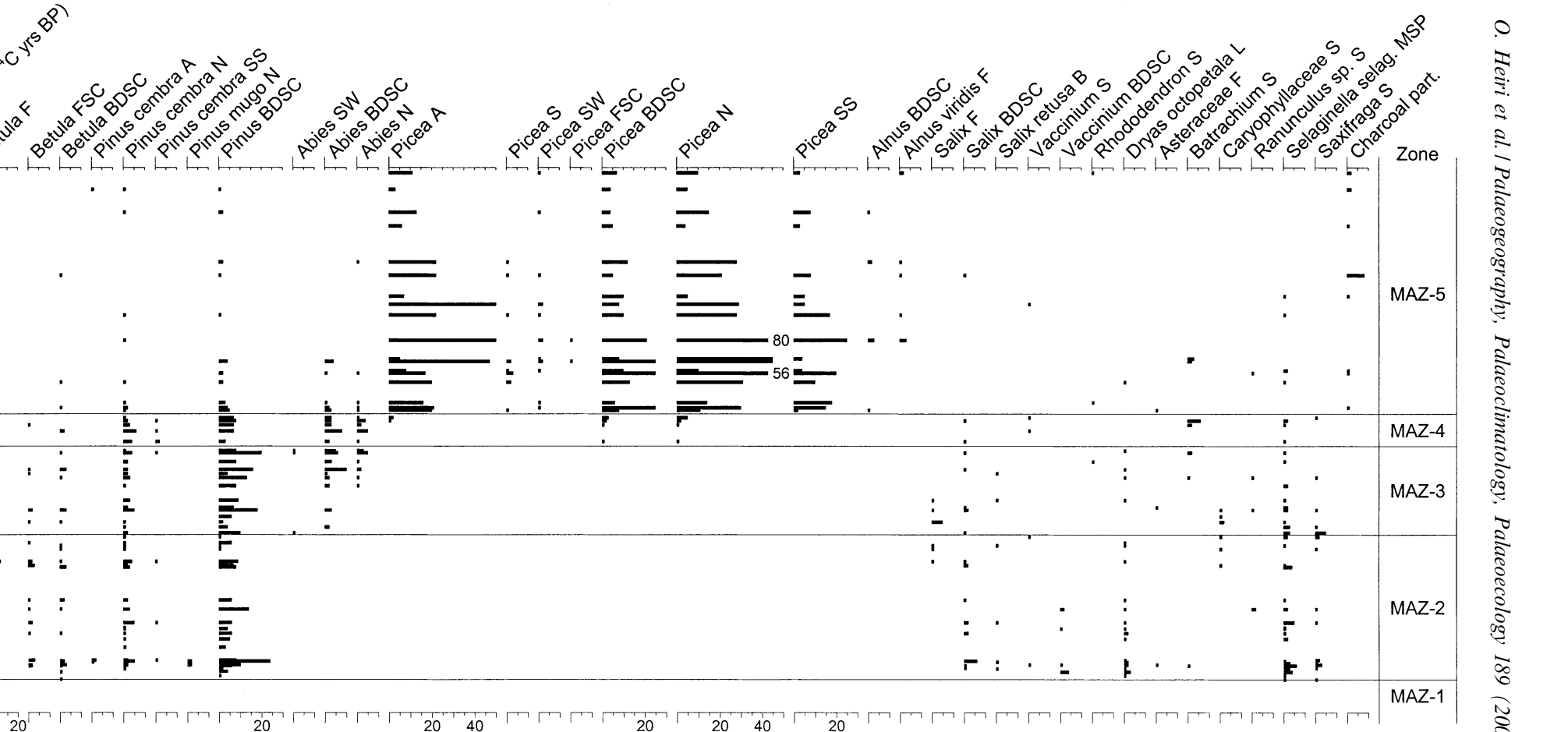

Fig. 4. Plant macrofossils of selected taxa found in the Hinterburgsee sediment. Values are in remains per $30-40 \mathrm{~cm}^{3}$ sample volume for anthers (A), bud scales (BDSC), fruits (F), fruit scales (FSC), leaves (L), macrospores (MSP), needles (N), seeds (S), short shoots (SS), and seed wings (SW). Periderm, wood and fragments with less than three occurrences are not shown. No samples younger than $1300 \mathrm{cal}$. BP were analysed. 
ments of Hinterburgsee before 11000 cal. BP contained hardly any plant macrofossils (macrofossil assemblage zone (MAZ)-1; Fig. 4). After ca. 11000 cal. BP the first macrofossils of Betula, Pinus cembra and Pinus mugo were found. Remains of these three trees, together with remains of heliophilous herbs and shrubs (e.g. Salix retusa, Dryas octopetala, Selaginella selaginoides and Saxifraga), remained abundant in the sediment of Hinterburgsee until ca. 5000-6000 cal. BP (MAZ2, 3, 4). A number of Betula remains were identifiable as belonging to Betula pubescens. At ca. $8200 \mathrm{cal}$. BP the first bud scales of Abies were found. However, it takes another ca. 700 years until a significant increase of Abies macrofossils is apparent in the sediment. A strong increase in Picea macrofossils is apparent around 6000 cal. $\mathrm{BP}$, about 500 years after the first remains were found in the sediments. At the same time the remains of dwarf shrubs and herbs become sparse. After reaching maximum values at the beginning of MAZ-5 (between ca. 5500 and 4000 cal. BP) the abundance of Picea macrofossils decreases again. Compared to the high percentages of Alnus viridis in the pollen stratigraphy, Alnus macrofossils were sparse in the Hinterburgsee sediment. However, this may be explained by the generally poor preservation of Alnus viridis remains in lake sediments. The first macroscopic charcoal remains were found in Hinterburgsee at ca. $5800 \mathrm{cal}$. BP, just after the expansion of Picea in the catchment. Additional charcoal was found in younger sediments, although with no clear maximum. The absence of macrofossils of Corylus, Ulmus, Tilia, Quercus and Alnus glutinosa suggests that these trees did not grow in Hinterburgsee's catchment and that the high percentages of these pollen types in the sediments are due to long-distance pollen transport. No samples younger than 1300 cal. BP were analysed for macrofossils.

\subsection{Chironomids}

The samples in the deepest Hinterburgsee sediments (chironomid assemblage zone-1; CAZ-1) are dominated by Heterotrissocladius grimshawitype, Micropsectra radialis-type, Paracladius and Procladius (Fig. 5). At the Younger Dryas/Holo- cene boundary (ca. 11500 cal. BP) a single sample shows a very high abundance of Tanytarsus lugens-type, whereas Heterotrissocladius grimshawi-type and Paracladius disappear. Micropsectra radialis-type and Procladius, however, persist during the whole CAZ-2. In addition, a series of new taxa appear, e.g. Ablabesmyia, Heterotrissocladius marcidus-type, Micropsectra spp., Microtendipes and Stictochironomus. Zavrelimyia A, which is already present in low numbers during the Younger Dryas, shows a first slight increase at the beginning of CAZ-2 only to decrease again during the second part of the zone.

A strong increase of Zavrelimyia A and the almost complete disappearance of Procladius and Micropsectra radialis-type mark the beginning of CAZ-3. The abundance of Zavrelimyia A remains high during the rest of the Holocene. CAZ-3 is further characterised by a more or less constant presence of Chironomus anthracinus-type and the first occurrences of, among others, Corynoneura scutellata-type, Chironomus plumosus-type and Psectrocladius (s.str.). A number of taxa disappear for a short sequence in the middle of the zone around ca. 8600-7600 cal. BP (e.g. Paratanytarsus spp., Cricotopus-type, Tanytarsus A, Parakiefferiella; Fig. 5). During the same period $\mathrm{Mi}$ cropsectra spp. have their highest abundance. In CAZ-4, Tanytarsus lugens-type shows a marked increase and Procladius reappears, although the few Procladius thoracic horns found in the younger sediments suggest that it is not the same species as in CAZ-1 and 2 (Fig. 5). A number of taxa that were present at the beginning of the zone disappear within CAZ-4, e.g. Ablabesmyia, Heterotrissocladius marcidus-type and Micropsectra spp. Towards the top of the core Zavrelimyia A and Tanytarsus spp. increase, whereas Tanytarsus lugens-type decreases. Total chironomid head capsule concentrations show very large fluctuations in the Hinterburgsee stratigraphy and range from 0.8 to 130 head capsules per $\mathrm{cm}^{3}$ with very low values in CAZ-2 and parts of CAZ-3. Even though the Hinterburgsee stratigraphy is well dated, the calculation of head capsule accumulation rates did not help in the interpretation of the chironomid stratigraphy or explain the large changes in chironomid concentrations. 

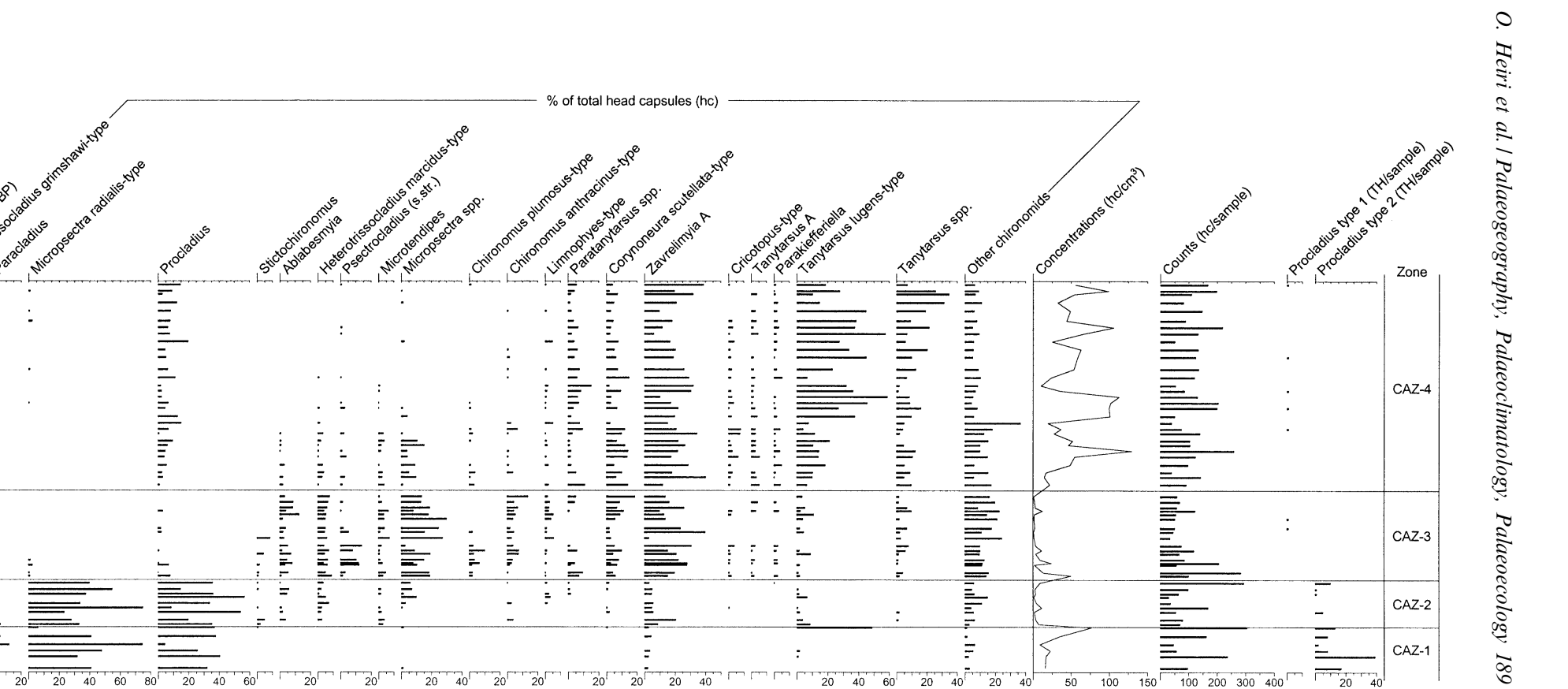

Fig. 5. Chironomid stratigraphy of Hinterburgsee. Larval remains are given as percentages of the total number of head capsules (hc) except for concentrations (hc per $\mathrm{cm}^{3}$ ) and counts (hc per sample). Pupal remains are given as thoracic horns (TH) per sample. 


\section{Discussion}

\subsection{Vegetation development}

The Late Glacial and earliest Holocene sediments of Hinterburgsee before 11000 cal. BP indicate a sparse and treeless vegetation in the lake's catchment (Fig. 4). This agrees with other palaeobotanical studies in the region (e.g. Wegmüller and Lotter, 1990; Tobolski and Ammann, 2000; Wick, 2000), which suggest a treeline in the Bernese Alps below $1300 \mathrm{~m}$ asl during the Younger Dryas. At Hinterburgsee local reforestation by Pinus cembra, Betula pubescens and Pinus mugo took place about 500 years after the end of the Younger Dryas (ca. 11000 cal. BP). Pinus cembra and Betula pubescens formed the catchment forests for the following 3000 years. However, remains of many pioneer species among dwarf shrubs and herbs, such as Salix retusa, Dryas octopetala, Selaginella selaginoides and Saxifraga sp. (Fig. 4), indicate that the vegetation was still fairly open and the soils poorly developed. In addition, the high sedimentation rates and the lithology of the lower part of the core (low organic matter and high carbonate content) suggest high allochthonous sediment input into the lake (Fig. $2 \mathrm{~b}, \mathrm{c})$. The findings that open Pinus cembra and Betula pubescens forests formed the woodlands just below the timberline in the Bernese Alps agree well with the results of Wegmüller and Lotter (1990) from two localities ca. $45 \mathrm{~km}$ west of Hinterburgsee. According to their study, the subalpine vegetation at timberline in the early Holocene consisted of open stands of Pinus cembra, Betula and possibly scattered individuals of Pinus mugo and Larix. However, since strong southerly winds are a common phenomenon in the northern Swiss Alps, the presence of Larix pollen at their sites may possibly be the consequence of long-distance transport from the Central Alps. In a palaeobotanical study based on pollen and plant macrofossil analysis of lake sediments, Wick et al. (accepted) studied the Holocene vegetation development near Sägistalsee (1935 m asl), an alpine lake situated $8 \mathrm{~km}$ southwest of Hinterburgsee. Their study indicates that Larix was never a major constituent of the local vegetation. Our results support the conclusion of Wick et al. (accepted) that Larix, an important component of early Holocene treelines in the Central and Southern Alps, was largely absent from the Hinterburgsee region.

At Hinterburgsee, the first scattered Abies macrofossils were found as early as 8200 cal. BP, although it was not until ca. $7400 \mathrm{cal}$. BP that Abies began to expand and became a major component of the local vegetation. This is considerably later than at Sägistalsee, where Abies expanded into the lake catchment as early as 8500 cal. BP (Wick et al., accepted). Changes in sediment composition (increase of organic matter and decrease of carbonate) after the expansion of Abies (ca. 7100-6000 cal. BP) indicate that the vegetation in Hinterburgsee's catchment became progressively denser and more stable, causing a reduction in allochthonous sediment input into the lake (Fig. 6). As in other lakes in the region (e.g. Wick et al., accepted), Picea abies expanded in the catchment of Hinterburgsee at ca. $6000 \mathrm{cal}$. BP, followed by Alnus viridis at ca. 5000 cal. BP. Between 6000 and $5000 \mathrm{cal}$. BP the concentrations of macrofossils of heliophilous dwarf shrubs and herbs decrease (e.g. Salix, Dryas octopetala, Selaginella selaginoides). Together with the highest organic matter and lowest carbonate content in the sediments, this indicates that the forests were densest in the catchment from ca. 5500 to $2500 \mathrm{cal}$. BP. During this period Betula pubescens declines and Pinus cembra and Abies all but disappear from the local vegetation at Hinterburgsee.

A first rise in pollen indicating human presence (e.g. Plantago lanceolata) is registered in Hinterburgsee as early as 4000 cal. BP. It has been hypothesised that the expansion of Alnus viridis in the Alps was promoted by human activity (Wick and Tinner, 1997) and the high abundance of Alnus viridis pollen in the Hinterburgsee sediments after ca. 5000 cal. BP may be due to human presence in the region. However, it is not until ca. $2500 \mathrm{cal}$. BP that clear indications of an opening of the local vegetation are registered in the sediment composition (i.e. a lower concentration of tree macrofossils and a lower organic matter and higher carbonate content of the sediment, suggesting increased erosion). In the last 800 years 


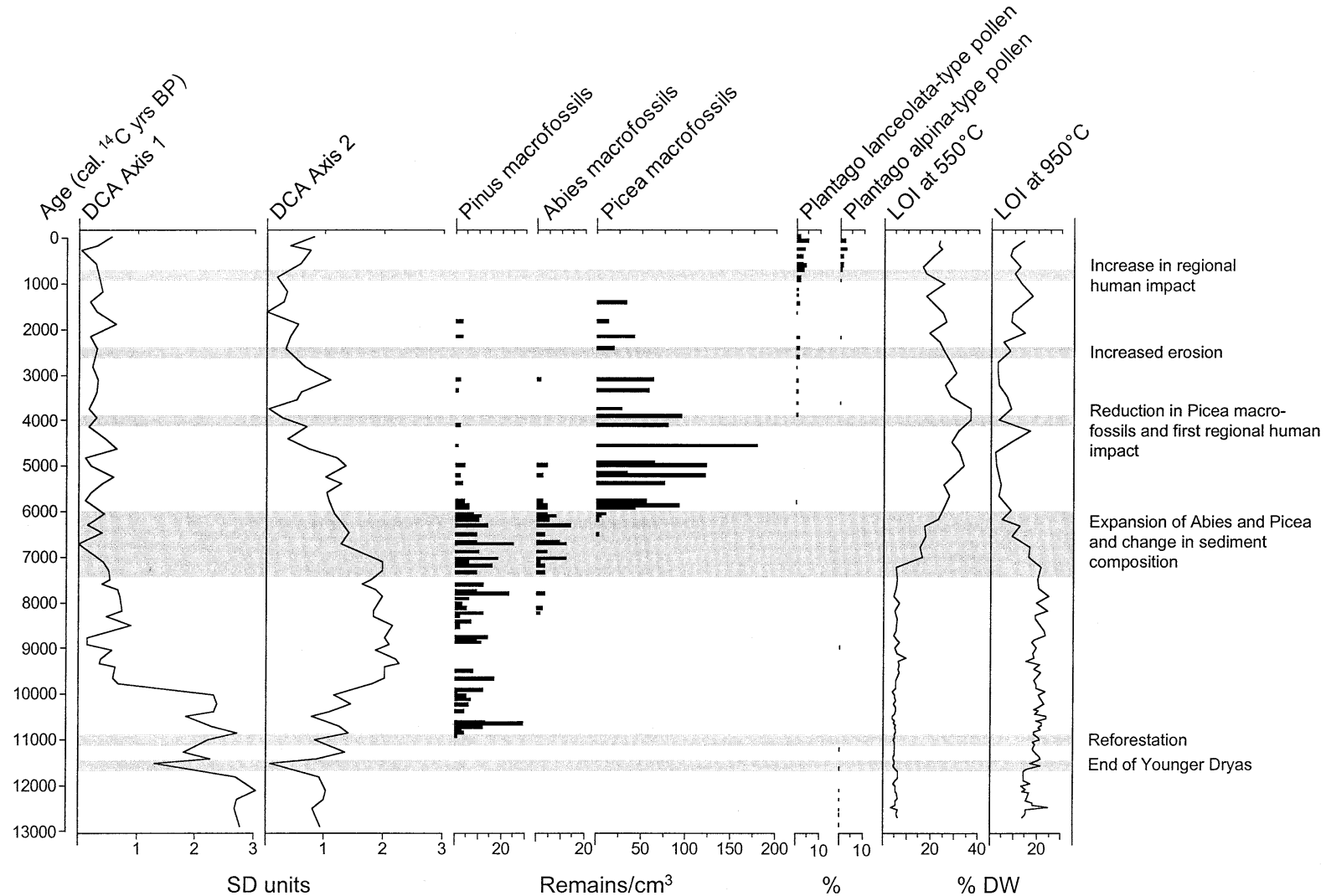

Fig. 6. Catchment events and the development of the chironomid fauna in Hinterburgsee. The chironomid data are summarised in the first two axes of a DCA. Axis scores are given in standard deviation units (SD). LOI, selected pollen types and summary plant macrofossil diagrams for Pinus, Abies and Picea are shown for comparison.

the pollen stratigraphy indicates strong human activity in the region, with a rise in Gramineae and many indicators of pasturing, e.g. Plantago lanceolata, Rumex acetosa and Plantago alpina. Analysed plant macrofossil samples are lacking from the topmost sediments. Nevertheless, the increase in herb pollen to almost 30\% indicates that the local vegetation was strongly affected by human activity.

\subsection{Major faunistic patterns in the chironomid stratigraphy}

Chironomid percentages in the Hinterburgsee sediments show a large amount of high frequency variability downcore, giving the stratigraphy a rather spiky appearance (Fig. 5). This variability seems to be typical of Swiss mountain lakes with high sedimentation rates (e.g. Heiri, 2001) and is possibly a consequence of the natural variability of the chironomid fauna, of taphonomy, or of the low abundance of chironomid remains in the sediment.

Late Glacial samples in Hinterburgsee (i.e. those before 11500 cal. BP) show a chironomid assemblage typical of alpine lakes. Heterotrissocladius grimshawi and Micropsectra radialis have been found in high alpine lakes in Austria (Bretschko, 1974; Zaderer, 1982). In small lakes in Switzerland, Paracladius and these two taxa occur mainly above $1750 \mathrm{~m}$ asl, whereas Zavrelimyia A can be found from 750 to over $2000 \mathrm{~m}$ asl (see Heiri, 2001, for distributional data on the chironomid taxa). Procladius occurs over a wide temperature gradient in Swiss lakes. However, the pupal remains found in the sediments suggest that 
the Procladius species present in Hinterburgsee in the Late Glacial and earliest Holocene is a cold stenothermous species. Procladius pupal exuviae with similar thoracic horns to Procladius type 2 have been described from the High Tatra Mountains, former Czechoslovakia (Gowin and Zavrel, 1944), and have been found in the Central Pyrenees (M. Rieradevall, personal communication) and in Holocene cores from alpine lakes in the French Maritime Alps and the Swiss Alps (O. Heiri, unpublished information).

Heterotrissocladius grimshawi-type and Paracladius disappear from the stratigraphy at the end of the Younger Dryas. Micropsectra radialis-type and Procladius type 2, however, persist well into the Holocene and are joined by a series of new taxa, some with a predominantly alpine/subalpine distribution (e.g. Micropsectra spp., Heterotrissocladius marcidus-type), others with warmer temperature preferences (e.g. Ablabesmyia, Microtendipes; see Heiri, 2001). A strong change in the chironomid stratigraphy is apparent at ca. 10000 cal. BP, with a distinct increase of Zavrelimyia $\mathrm{A}$ and the almost complete disappearance of Procladius and Micropsectra radialis-type. From 10000 cal. BP onwards there is a trend in the stratigraphy from a chironomid assemblage dominated by taxa such as Micropsectra spp., Heterotrissocladius marcidus-type, and Ablabesmyia to one increasingly dominated by Tanytarsus lugens-type, with a parallel increase in Procladius (presumably Procladius type 1) and Tanytarsus spp. Other taxa, however, show comparatively little change in the last 10000 years (e.g. Corynoneura scutellata-type, Zavrelimyia A).

Given the clear Holocene succession in both the plant macrofossil and the chironomid stratigraphy, a possible cause for the shifts in the chironomid fauna is changes in the local catchment vegetation. According to our data the following major events can be identified in the catchment development (Fig. 6): (1) the end of the Younger Dryas at ca. 11500 cal. BP, (2) the reforestation of the catchment by Pinus cembra and Betula pubescens at ca. $11000 \mathrm{cal}$. BP, (3) the expansion of Abies between ca. 7400 and 7100 cal. BP with the associated change in sediment composition between ca. 7100 and 6000 cal. BP, (4) the expan- sion of Picea in the catchment at ca. 6000 cal. BP, (5) the reduction of Picea macrofossils and the first regional human impact at ca. 4000 cal. BP, (6) the slight change in sediment chemistry at ca. 2500 cal. BP, suggesting an opening of local forests and increased erosion, and (7) the strong increase of grazing indicator pollen at ca. $800 \mathrm{cal}$. $\mathrm{BP}$, implying a significant increase in local and regional human activity.

For comparison with palaeobotanical and sedimentological data the chironomid results are summarised using DCA (Hill and Gauch, 1980) and plotted on an age scale (Fig. 6). The scaling in 'standard deviation' units of change provides an estimate of species turnover within the chironomid data (Birks, 1998). DCA produced two significant axes (tested following Birks, 1998) that explained $44 \%$ of cumulative variance in the chironomid data $\left(\lambda_{1}=0.65, \lambda_{2}=0.25\right.$, total inertia $=2.1)$. The first axis separates chironomid assemblages before 10000 cal. BP from younger samples (Fig. 6). On the second axis Late Glacial and early Holocene samples before 10000 cal. BP have intermediate scores, samples between ca. 10000 and $7000 \mathrm{cal}$. BP high scores and between ca. 7000 and $4500 \mathrm{cal}$. BP there is a gradual trend to the low values that dominate the late Holocene. In a DCA the change in standard deviations per unit of time can provide an estimate of the rate of change within a stratigraphy (e.g. Jacobson and Grimm, 1986). The most abrupt shifts in standard deviation values of the first two axes take place at ca. 10000 cal. BP and just before and after the Younger Dryas/Holocene boundary (Fig. 6).

At the end of the Younger Dryas, an abrupt increase of temperatures has been inferred for the Alpine region (e.g. Lotter et al., 2000) and this most likely caused the elimination of the alpine taxa Heterotrissocladius grimshawi-type and Paracladius from Hinterburgsee. A comparison with the plant macrofossil and pollen data reveals that none of the remaining major shifts in the chironomid data coincide with changes in the catchment vegetation (Fig. 6). Just after local reforestation the first DCA axis values show a slight increase. However, this fluctuation is well within the early Holocene variability in DCA axis scores. The changing sediment composition indicates that 
the expansion of Abies and Picea in Hinterburgsee's catchment clearly affected the limnology of the lake (Fig. 6). A gradual decrease in the second axis scores of the chironomid-based DCA begins shortly after the expansion of Abies. However, this trend is not very abrupt, not apparent in the first DCA axis, and continues after the expansion of Picea in the lake catchment. The organic content of lake sediments has repeatedly been reported as having a significant influence on subfossil chironomid assemblages (e.g. Olander et al., 1999; Laroque et al., 2001). The decreasing trend in DCA axis 2 is accompanied by an increase in sediment organic matter content and a distinct decrease in axis 2 scores takes place synchronously to the initial rise in LOI at $550^{\circ}$ at ca. 7000 cal. BP. However, the strongest decrease in this axis takes place later (ca. $4700 \mathrm{cal}$. BP) when LOI at $550^{\circ} \mathrm{C}$ is already close to its maximum value. A closer look at the chironomid stratigraphy reveals that this trend is mainly caused by an increase of Tanytarsus lugens-type, a taxon with very low second axis scores. In small Swiss lakes, high percentages of Tanytarsus lugens-type are restricted to the shallower ones (e.g. all lakes with more than 30\% Tanytarsus lugens-type head capsules in their surface sediments have a maximum lake depth of $7 \mathrm{~m}$ or less; see Heiri, 2001). One of the major complications of using palaeolimnological techniques in lakes with high sedimentation rates over long time scales is that the infilling of the lake basin may change limnological processes (Anderson and Battarbee, 1994) and, therefore, can cause successional trends in aquatic communities. Assuming a constant water surface, the maximum lake depth of Hinterburgsee has decreased from $23 \mathrm{~m}$ in the earliest Holocene to $11 \mathrm{~m}$ at present. Thus, the successive decrease of lake depth may have been partly responsible for the increasing importance of Tanytarsus lugens-type (note, however, that a single early Holocene sample already had a high percentage value of this taxon). The only catchment signal that is clearly paralleled by changes in the chironomid stratigraphy is the rise in pollen, indicating regional pasturing at ca. $800 \mathrm{cal}$. BP, which is accompanied by an increase in the second DCA axis scores and in Tanytarsus spp. (Figs. 5 and 6).
Given the distinct changes in catchment vegetation and sediment composition, the lack of clear corresponding signals in the chironomid stratigraphy is unexpected. Most studies reporting a strong change of aquatic organism assemblages across treeline are from the circumpolar tundra/ forest ecotone (e.g. Walker and MacDonald, 1995; Porinchu and Cwynar, 2000; Smol and Cumming, 2000). In these regions the most significant limnological variable changing across treeline (besides temperature) is water chemistry, e.g. $\mathrm{pH}$, the concentrations of nutrients and dissolved organic carbon (DOC; e.g. MacDonald et al., 1993; Pienitz et al., 1999). However, small lakes in the Swiss Alps differ from arctic lowland lakes in a number of important characteristics, such as lake bathymetry, catchment topography and climate. Compared with many continental circumpolar regions the Alps receive a considerable amount of precipitation even in dry regions (Schär et al., 1998) and this, together with the steep topography, leads to high weathering and erosion rates. Lakes with steep catchment slopes seem to be less affected by high DOC concentrations (Rasmussen et al., 1989). Furthermore, as Hinterburgsee is situated on calcareous bedrock it features a high lake water $\mathrm{pH}$ and conductivity, and is therefore not prone to acidification. In addition, calcium precipitates humic matter (Stumm and Morgan, 1981, in Rasmussen et al., 1989) and thus DOC may have been rapidly eliminated from the lake.

In modern water chemistry measurements from small Swiss lakes (Müller et al., 1998) there is no clear change across timberline elevation (presently at ca. $1700-1800 \mathrm{~m}$ asl in the Northern Alps and up to 2300-2400 $\mathrm{m}$ asl in the Central Alps; Burga and Perret, 1998). However, the chemistry of even remote Swiss lakes is influenced by human activity, e.g. by acid precipitation (Boggero et al., 1998) or pasturing and extant lakes may therefore not represent good analogues to assess the relationship between catchment vegetation and lake water chemistry during the early and mid-Holocene. Nevertheless, distributional data on aquatic biota indicate that the strongest changes with altitude presently take place below the timberline in the Swiss Alps (Lotter et al., 1997a). 
In the Hinterburgsee stratigraphy the strongest change in the chironomid assemblages clearly occurs at ca. 10000 cal. BP (Figs. 5 and 6). However, there is no corresponding event in the sedimentological or palaeobotanical data. Furthermore, even though several Holocene climate oscillations have been described for the Swiss Alps and lowland regions (Wick and Tinner, 1997; Haas et al., 1998), none coincides with the disappearance of Micropsectra radialis-type and Procladius type 2 in Hinterburgsee. According to Kutzbach and Webb (1993), 9000 cal. BP is considered to be the time within the Holocene with the strongest summer insolation in northern temperate and arctic regions and, consequently, to have featured the warmest summer temperatures. Therefore, the disappearance of the last Late Glacial chironomid taxa coincides with a period of slowly but continuously increasing summer insolation. Holocene climate is still poorly understood in the Alpine region and it is not clear if summer temperature followed these insolation changes. However, a gradual increase of early Holocene summer temperature remains a possible reason for the abrupt change of the chironomid assemblages at ca. $10000 \mathrm{cal}$. BP. The effects of warmer climate on the cold adapted chironomid fauna could possibly have been aggravated by the decreasing lake depth of Hinterburgsee. Deep lakes often maintain cold (i.e. $4^{\circ} \mathrm{C}$ ) and well oxygenated water in their hypolimnion even in the Swiss lowlands. Micropsectra radialis-type head capsules are common in small lakes only at high elevations (Heiri, 2001), but Micropsectra radialis is present at low elevations in many of the deep prealpine lakes in northern Switzerland (e.g. Reiss, 1968; Schürch, 1985). As lake depth decreases the susceptibility to anoxia in the profundal increases (Frey, 1988). Furthermore, summer thermal stratification in shallow lakes becomes weaker and this can lead to higher temperatures at the lake bottom (Livingstone and Schanz, 1994). Assuming the same lake level as today, Hinterburgsee's depth has decreased from $23 \mathrm{~m}$ at the end of the Younger Dryas to $19 \mathrm{~m}$ at $10000 \mathrm{cal}$. BP. Possibly the joint pressure of increasing summer temperatures and decreasing lake depth caused the abrupt extinction of the cold adapted Late
Glacial relicts that had previously been able to persevere in Hinterburgsee.

\section{Conclusions}

In contrast to lakes at the circumpolar treeline, where local reforestation has been shown to rapidly have an effect on aquatic ecosystems (MacDonald et al., 1993; Pienitz et al., 1999), we found no clear relationship between the expansion of forests and the development of the chironomid fauna at Hinterburgsee. The increasingly dense woodlands in the catchment may have influenced the chironomid fauna by reducing erosion and increasing the organic matter content of the sediments. However, the succession in the chironomid stratigraphy between ca. 7000 and $4000 \mathrm{cal}$. BP (Fig. 6) may also have been caused or reinforced by the sediment infilling of the lake basin. Our results suggest that the effect of changing catchment vegetation on the chironomid fauna may be less pronounced in subalpine lakes than in subarctic lowland lakes. However, Hinterburgsee is only a single-case study. As the lake is situated on calcareous bedrock with high erosion rates it is not susceptible to acidification or to high DOC concentrations, factors which affect the limnology of lakes at the arctic treeline. Subalpine lakes on silicate bedrock or with more gentle catchment slopes may react differently to catchment reforestation and tree immigration. Finally, most inferences of lake water chemistry changes due to catchment reforestation are based on algal microfossils (Lotter et al., 1999; Smol and Cumming, 2000). Due to the high content of clay and silt in parts of the sediments, diatom analysis was not possible for Hinterburgsee. The inclusion of diatoms in future studies addressing the effect of catchment vegetation on subalpine lakes would provide important supplementary information on water chemistry changes too weak to be registered by the chironomid fauna.

None of the major Holocene events in Hinterburgsee's catchment caused a clear and immediate reaction in the chironomid fauna, with the possible exception of the increased human impact during the last ca. 800 years. For subalpine lakes on 
calcareous bedrock in the Alps this implies that reforestation and tree immigration are not likely to cause a distinct short-term bias in chironomidbased climate reconstruction. However, the longterm development of soils and forests may possibly be responsible for trends on a longer time scale in chironomid stratigraphies. Therefore, chironomid-inferred Holocene climate reconstructions in the Alpine region should ideally be based on a number of sites with a different vegetation and catchment history (e.g. different forest types or different immigration ages for dominant tree species) to reduce the possibility of an error in the reconstruction due to catchment-lake interactions. The quantity and preservation of tree macrofossils may differ substantially from one tree species to the next (e.g. Ammann and Wick, 1993) and the density of catchment forests may be difficult to assess based on plant macrofossil analysis alone. Sediment composition and changes in sedimentation rates provide useful supplementary information to assess the effects of catchment vegetation changes on sedimentological processes in the lake. Chironomid-inferred climate signals that parallel distinct changes in sediment composition should certainly be treated with caution.

Although this study suggests that catchment vegetation changes are not a major factor affecting the Holocene development of chironomid assemblages in subalpine lakes in the Alpine region, further work is needed to resolve the issue. An important question that remains to be answered is whether the influence of vegetation on the chironomid fauna is more distinct in subalpine lakes with smaller catchments and gentler catchment topography, or in lakes on silicate bedrock.

\section{Acknowledgements}

H.J.B. Birks and E. Heegaard provided the age-depth model for Hinterburgsee. M. Rieradevall pointed out that Procladius type 2 had previously been described and supplied information on its occurrence in the Pyrenees. We thank everyone involved in field work and processing of the sediment, including S. Hausmann, A. Hirt, L. Lanci, P. Kaltenrieder, C. Ohlendorf, E.
Sayer, M. Sturm, and W. Tanner. Special thanks are due to F. Oberli for the chemical processing of chironomid samples. M. Zeh of the Gewässer und Bodenschutzlabor des Kantons Bern (GBL) gave us access to water chemistry data of Hinterburgsee and W. Finsinger to sediment samples from Lac des Grenouilles, French Maritime Alps. E. Sayer improved the language and J.N. Haas and an anonymous referee provided valuable comments on the manuscript. Funding was provided by the Swiss Federal Office of Education and Science (Grant No. 97.0117) within the framework of the European Union Environment and Climate project CHILL-10,000 ('Climate history as recorded by ecologically sensitive arctic and alpine lakes during the last 10,000 years: a multi-proxy approach'; Contract No. ENV4-CT97-0642) and by the Swiss National Science Foundation within the framework of Priority Programme Environment (project 5001-044600).

\section{References}

Ammann, B., 2000. Biotic responses to rapid climatic changes: introduction to a multidisciplinary study of the Younger Dryas and minor oscillations on an altitudinal transect through the Alps. Palaeogeogr. Palaeoclimatol. Palaeoecol. 159, 191-201.

Ammann, B., Wick, L., 1993. Analysis of fossil stomata of conifers as indicators of the alpine tree line fluctuations during the Holocene. In: Frenzel, B. (Ed.), Oscillations of the Alpine and Polar Tree Limits in the Holocene. Gustav Fischer Verlag, Stuttgart, pp. 177-185.

Ammann, B., Gaillard, M.-J., Lotter, A.F., 1996. Switzerland. In: Berglund, B.E., Birks, H.J.B., Ralska-Jasiewiczowa, M., Wright, H.E. (Eds.), Palaeoecological Events During the Last 15,000 Years: Regional Syntheses of Palaeoecological Studies of Lakes and Mires in Europe. John Wiley and Sons, Chichester, pp. 647-666.

Anderson, N.J., 2000. Diatoms, temperature, and climate change. Eur. J. Phycol. 35, 307-314.

Anderson, N.J., Battarbee, R.W., 1994. Aquatic community persistence and variability. A palaeolimnological perspective. In: Giller, P.S., Hildrew, A.G., Raffaelli, D. (Eds.), Aquatic Ecology: Scale, Patterns and Processes. Blackwell Scientific Publications, London, pp. 233-259.

Beniston, M., Diaz, H.F., Bradley, R.S., 1997. Climatic changes at high elevation sites: an overview. Clim. Change 36, 233-251.

Birks, H.J.B., 1995. Quantitative palaeoenvironmental reconstructions. In: Maddy, D., Brew, J.J. (Eds.), Statistical 
Modelling of Quaternary Science Data. Quaternary Research Association, Cambridge, pp. 161-254.

Birks, H.J.B., 1998. Numerical tools in palaeolimnology progress, potentialities, and problems. J. Paleolimnol. 20, 307-332.

Boggero, A., Barbieri, A., de Jong, J., Marchetto, A., Mosello, R., 1998. Chemistry and critical loads of Alpine lakes in Canton Ticino (Southern Swiss Alps). Aquat. Sci. 60, 300315.

Bradley, R.S., 2000. Past global changes and their significance for the future. Quat. Sci. Rev. 19, 391-402.

Bretschko, G., 1974. The chironomid fauna of a high-mountain lake (Vorderer Finstertaler See, Tyrol, Austria, 2237 m asl). Entomol. Tidskr. Suppl. 95, 22-33.

Burga, C., 1993. Swiss alpine palaeoclimate during the Holocene: pollen analytical evidence and general features. In: Frenzel, B. (Ed.), Solifluction and Climatic Variation in the Holocene. Gustav Fischer Verlag, Stuttgart, pp. 11-21.

Burga, C.A., Perret, R., 1998. Vegetation und Klima der Schweiz seit dem jüngeren Eiszeitalter. Ott Verlag and Druck, Thun.

Fægri, K., Iversen, J., 1989. Textbook of Pollen Analysis. John Wiley and Sons, Chichester.

Frey, D.G., 1988. Littoral and offshore communities of diatoms, cladocerans, and dipterous larvae, and their interpretation in paleolimnology. J. Paleolimnol. 1, 179-191.

Gowin, F., Zavrel, J., 1944. Novy Procladius z vysokych Tater. Procladius tatrensis Gow. n. sp.. Entomol. Listy (Folia Entomol.) 7, 87-90.

Guthruf, J., Guthruf-Seiler, K., Zeh, M., 1999. Kleinseen im Kanton Bern. Gewässer und Bodenschutzlabor des Kantons Bern (GBL), Bern.

Haas, J.N., Richoz, I., Tinner, W., Wick, L., 1998. Synchronous Holocene climate oscillations recorded on the Swiss Plateau and at timberline in the Alps. Holocene 8, 301-309.

Heiri, O., 2001. Holocene Palaeolimnology of Swiss Mountain Lakes Reconstructed Using Subfossil Chironomid Remains: Past Climate and Prehistoric Human Impact on Lake Ecosystems. Ph.D. Thesis, University of Bern, Switzerland.

Heiri, O., Lotter, A.F., Lemcke, G., 2001. Loss on ignition as a method for estimating organic and carbonate content in sediments: reproducibility and comparability of results. J. Paleolimnol. 25, 101-110.

Hill, M.O., Gauch, H.G., 1980. Detrended correspondence analysis: an improved ordination technique. Vegetatio 42, 47-58.

Hofmann, W., 1971. Zur Taxonomie und Palökologie subfossiler Chironomiden (Dipt.) in Seesedimenten. Arch. Hydrobiol. Beih. 6, 1-50.

Itkonen, A., Marttila, V., Meriläinen, J.J., Salonen, V.-P., 1999. 8000-year history of palaeoproductivity in a large boreal lake. J. Paleolimnol. 21, 271-294.

Jacobson, G.L., Grimm, E.C., 1986. A numerical analysis of Holocene forest and prairie vegetation in central Minnesota. Ecology 67, 958-966.

Korsman, T., Renberg, I., Anderson, N.J., 1994. A palaeolimnological test of the influence of Norway spruce (Picea abies) immigration on lake water acidity. Holocene 4, 132 140.

Kutzbach, J.E., Webb, T., III, 1993. Conceptual basis for understanding Late-Quaternary climates. In: Wright, H.E., Jr. (Ed.), Global Climates Since the Last Glacial Maximum, University of Minnesota Press, Minneapolis, MN, pp. 5-11.

Langton, P.H., 1991. A Key to Pupal Exuviae of West Palaearctic Chironomidae. Privately published by P.H. Langton, 3 St Felix Road, Ramsey Forty Foot, Huntingdon, Cambridgeshire, UK.

Laroque, I., Hall, R.I., Grahn, E., 2001. Chironomids as indicators of climate change: a 100-lake training set from a subarctic region of northern Sweden (Lapland). J. Paleolimnol. 26, 307-322.

Levesque, A.J., Mayle, F.E., Walker, I.R., Cwynar, L.C., 1993. A previously unrecognized late-glacial cold event in eastern North America. Nature 361, 623-626.

Livingstone, D.M., Schanz, F., 1994. The effects of deep-water siphoning on a small, shallow lake: a long-term case study. Arch. Hydrobiol. 132, 15-44.

Lotter, A.F., 2001. The palaeolimnology of Soppensee (Central Switzerland), as evidenced by diatom, pollen, and fossil pigment analyses. J. Paleolimnol. 25, 65-79.

Lotter, A.F., Birks, H.J.B., accepted. Holocene sediments of Sägistalsee, a small lake at the present-day tree-line in the Swiss Alps. J. Paleolimnol.

Lotter, A.F., Birks, H.J.B., Hofmann, W., Marchetto, A., 1997a. Modern diatom, cladocera, chironomid, and chrysophyte cyst assemblages as quantitative indicators for the reconstruction of past environmental conditions in the Alps. I. Climate. J. Paleolimnol. 18, 395-420.

Lotter, A.F., Merkt, J., Sturm, M., 1997b. Differential sedimentation versus coring artifacts: a comparison of two widely used piston-coring methods. J. Paleolimnol. 18, 7585.

Lotter, A.F., Birks, H.J.B., Hofmann, W., Marchetto, A., 1998. Modern diatom, cladocera, chironomid, and chrysophyte cyst assemblages as quantitative indicators for the reconstruction of past environmental conditions in the Alps. II. Nutrients. J. Paleolimnol. 19, 443-463.

Lotter, A.F., Pienitz, R., Schmidt, R., 1999. Diatoms as indicators of environmental change near arctic and alpine treeline. In: Stoermer, E.F., Smol, J.P. (Eds.), The Diatoms: Applications for the Environmental and Earth Sciences. Cambridge University Press, Cambridge, pp. 205-226.

Lotter, A.F., Birks, H.J.B., Eicher, U., Hofmann, W., Schwander, J., Wick, L., 2000. Younger Dryas and Allerød summer temperatures at Gerzensee (Switzerland) inferred from fossil pollen and cladoceran assemblages. Palaeogeogr. Palaeoclimatol. Palaeoecol. 159, 349-361.

MacDonald, G.M., Edwards, T.W.D., Moser, K.A., Pienitz, R., Smol, J.P., 1993. Rapid response of treeline vegetation and lakes to past climate warming. Nature 361, 243-246.

Merkt, J., Streif, H., 1970. Stechrohr-Bohrgeräte für limnische und marine Lockersedimente. Geol. Jahrb. 88, 137-148.

Meyer, E., 1990. A simple subsampling device for macroinver- 
tebrates with general remarks on the processing of stream benthos samples. Arch. Hydrobiol. 117, 309-318.

Müller, B., Lotter, A.F., Sturm, M., Ammann, A., 1998. Influence of catchment quality and altitude on the water and sediment composition of 68 small lakes in Central Europe. Aquat. Sci. 60, 316-337.

Olander, H., Birks, H.J.B., Korhola, A., Blom, T., 1999. An expanded calibration model for inferring lakewater and air temperatures from fossil chironomid assemblages in northern Fennoscandia. Holocene 9, 279-294.

Pienitz, R., Smol, J.P., MacDonald, G.M., 1999. Paleolimnological reconstruction of Holocene climatic trends from two boreal treeline lakes, Northwest Territories, Canada. Arct. Antarct. Alp. Res. 31, 82-93.

Porinchu, D.F., Cwynar, L.C., 2000. The distribution of freshwater Chironomidae (Insecta: Diptera) across treeline near the lower Lena River, Northeast Siberia, Russia. Arct. Antarct. Alp. Res. 32, 429-437.

Rasmussen, J.B., Godbout, L., Schallenberg, M., 1989. The humic content of lake water and its relationship to watershed and lake morphometry. Limnol. Oceanogr. 34, 13361343.

Reiss, F., 1968. Ökologische und systematische Untersuchungen der Chironomiden (Diptera) des Bodensees. Arch. Hydrobiol. 64, 176-246.

Renberg, I., 1991. The HON-Kajak sediment corer. J. Paleolimnol. 6, 167-170.

Rieradevall, M., Brooks, S.J., 2001. An identification guide to subfossil Tanypodinae larvae (Insecta: Diptera: Chironomidae) based on cephalic setation. J. Paleolimnol. 25, 81-99.

Schär, C., Davies, T.D., Frei, C., Wanner, H., Widmann, M., Wild, M., Davies, H.C., 1998. Current Alpine climate. In: Cebon, P., Dahinden, U., Davies, H.C., Imboden, D., Jaeger, C.C. (Eds.), Views From the Alps. Regional Perspectives on Climate Change. Massachusetts Institute of Technology Press, Cambridge, MA, pp. 21-72.

Schmid, P.E., 1993. A key to the larval Chironomidae and their instars from Austrian Danube region streams and rivers with particular reference to a numerical taxonomic approach. Part I. Diamesinae, Prodiamesinae and Orthocladiinae. Wasser Abwasser Suppl. 3/93, 1-514.

Schürch, M., 1985. Zur Faunistik und Ökologie der Chironomiden des Zürichsees. Ph.D. Thesis, Universität Zürich, Zürich.

Smol, J.P., Cumming, B.F., 2000. Tracking long-term changes in climate using algal indicators in lake sediments. J. Phycol. 36, 986-1011.

Spengler, D., 1973. Limnologische, hydrologische und morphologische Untersuchungen im Faulhorngebiet (Berner Oberland). Ph.D. Thesis, Universität Bern, Bern.

Stuiver, M., Reimer, P.J., 1993. Extended ${ }^{14} \mathrm{C}$ data base and revised CALIB radiocarbon calibration program. Radiocarbon 35, 215-230.
Stumm, W., Morgan, J.J., 1981. Aquatic Chemistry, Wiley, New York.

ter Braak, C.J.F., Smilauer, P., 1998. CANOCO Reference Manual and User's Guide to Canoco for Windows. Centre for Biometry, Wageningen.

Tobolski, K., Ammann, B., 2000. Macrofossils as records of plant responses to rapid Late Glacial climatic changes at three sites in the Swiss Alps. Palaeogeogr. Palaeoclimatol. Palaeoecol. 159, 251-259.

Tranquillini, W., 1979. Physiological Ecology of the Alpine Timberline: Tree Existence at High Altitudes with Special Reference to the European Alps. Springer, Berlin.

van der Knaap, W.O., Ammann, B., 1997. Depth-age relationships of 25 well-dated Swiss Holocene pollen sequences archived in the Alpine Palynological Data-Base. Rev. Paléobiol. Genève 16, 433-480.

Walker, I.R., Mathewes, R.W., 1989. Chironomidae (Diptera) remains in surficial lake sediments from the Canadian Cordillera: analysis of the fauna across an altitudinal gradient. J. Paleolimnol. 2, 61-80.

Walker, I.R., MacDonald, G.M., 1995. Distributions of Chironomidae (Insecta: Diptera) and other freshwater midges with respect to treeline, Northwest Territories, Canada. Arct. Alp. Res. 3, 258-263.

Walker, I.R., Mott, R.J., Smol, J.P., 1991a. Allerød-Younger Dryas lake temperatures from midge fossils in Atlantic Canada. Science 253, 1010-1012.

Walker, I.R., Smol, J.P., Engstrom, D.R., Birks, H.J.B., 1991b. An assessment of Chironomidae as quantitative indicators of past climatic change. Can. J. Fish. Aquat. Sci. 48, 975-987.

Wegmüller, S., Lotter, A.F., 1990. Palynostratigraphische Untersuchungen zur spät- und postglazialen Vegetationsgeschichte der nordwestlichen Kalkalpen. Bot. Helv. 100, 3773.

Wick, L., 2000. Vegetational responses to climatic changes recorded in Swiss Late Glacial lake sediments. Palaeogeogr. Palaeoclimatol. Palaeoecol. 159, 231-250.

Wick, L., Tinner, W., 1997. Vegetation changes and timberline fluctuations in the Central Alps as indicators of Holocene climate fluctuations. Arct. Alp. Res. 29, 445-458.

Wick, L., van Leeuwen, J.F.N., van der Knaap, W.O., Lotter, A.F., accepted. Holocene vegetation development in the catchment of Sägistalsee (1935 m asl), a small lake in the Swiss Alps. J. Paleolimnol.

Wiederholm, T., 1983. Chironomidae of the Holarctic region. Keys and diagnoses. Part I. Larvae. Entomol. Scand. Suppl. $19,1-457$.

Zaderer, P., 1982. Bestand und Produktion der Chironomiden des Grossenköllesees (2413 m ü. N.N.). Ph.D. Thesis, Universität Innsbruck, Innsbruck. 